\title{
Purinergic signalling in the cardiovascular system-a tribute to Geoffrey Burnstock
}

\author{
Vera Ralevic ${ }^{1}$ (D) \\ Received: 8 September 2020 / Accepted: 13 September 2020 / Published online: 5 November 2020 \\ (C) The Author(s) 2020
}

\begin{abstract}
Geoffrey Burnstock made groundbreaking discoveries on the physiological roles of purinergic receptors and led on P2 purinergic receptor classification. His knowledge, vision and leadership inspired and influenced the international scientific community. I had the privilege of spending over 10 years (from 1985) with Geoff at the Department of Anatomy and Developmental Biology, initially as a $\mathrm{PhD}$ student and then as a postdoctoral research fellow. I regarded him with enormous admiration and affection. This review on purinergic signalling in the cardiovascular system is a tribute to Geoff. It includes some personal recollections of Geoff.
\end{abstract}

Keywords ATP · Cardiovascular system · Purine receptors

\section{Classification of purine receptors}

Geoffrey Burnstock is immortalized in purinergic receptor classification which he drove through his research and conceptualisation of the functional and molecular evidence. Geoff recognized the importance of research in the adenosine receptor field and functional differences compared with ATP/ADP to propose that there are two main families of purinergic receptors: P1 receptors for adenosine and P2 receptors which can be activated by purine nucleotides (ATP, ADP) [1]. Geoff further proposed that $\mathrm{P} 2$ receptors are divided into two functionally distinct classes: P2X and P2Y receptors [2]. P2 receptors are also activated by pyrimidine nucleotides and nucleotide sugars (UTP, UDP, UDP-glucose) [3]. Adenosine P1 receptors are divided into A1, A2A, A2B, and A3 subtypes which belong to the $\mathrm{G}$ protein-coupled receptor (GPCR) superfamily [4-6]. The 1990s were a vibrant time in Geoff's laboratory as Geoff, together with Eric Barnard and colleagues, cloned the P2Y1 receptor [7] and news emerged about the cloning of the P2Y2

This article is part of the Topical Collection on A Tribute to Professor Geoff Burnstock.

Vera Ralevic

vera.ralevic@nottingham.ac.uk

1 School of Life Sciences, Queen's Medical Centre, University of Nottingham, Nottingham NG7 2UH, UK receptor [8] and first P2X receptors [9, 10], which contributed to the feeling of a gathering momentum in purinergic research. Adenosine receptors had already been cloned (see $[4,5]$ ). Geoff's excitement was palpable and infectious. Based on the molecular and functional evidence, Geoff proposed that P2 receptors are divided into two structurally and functionally distinct classes, ligand-gated ionotropic P2X receptors and G protein-coupled $\mathrm{P} 2 \mathrm{Y}$ receptors [11].

There are seven subtypes of P2X receptors (P2X1-7) and these ligand-gated ion channels are activated by extracellular ATP. P2X receptors are permeable to cations leading to depolarization and $\mathrm{Ca} 2+$ influx through voltage-gated calcium channels or slower $\mathrm{Ca} 2+-$ dependent responses [12, 13]. There are eight subtypes of G protein-coupled P2Y receptors: P2Y1, P2Y2, P2Y4, P2Y6, P2Y11, P2Y12, P2Y13, and P2Y14. P2Y receptors are activated by a variety of nucleotides including ATP, ADP, UTP, UDP, and UDP glucose [14-16]. P2Y1, P2Y2, $\mathrm{P} 2 \mathrm{Y} 4$, and P2Y6 receptors couple to Gq proteins and activate phospholipase $\mathrm{C}$ (PLC), leading to an increase in inositol triphosphate (IP3) and intracellular $\mathrm{Ca} 2+$ levels and activation of protein kinase C (PKC); P2Y12, P2Y13, and P2Y14 receptors are coupled to Gi proteins and cause inhibition of adenylyl cyclase (AC) activity resulting in a reduction in intracellular cyclic adenosine monophosphate (cAMP); P2Y11 receptors couple to both Gs and Gq proteins to activate PLC and AC [15-18].

Purinergic receptors can undergo heteromeric complex formation between the families, e.g. P2Y1 and P2Y2 heteromeric 
association with A1 receptors [19, 20], within the families, e.g. P2Y1-P2Y12 complex formation [21], and also with other receptors, e.g. A1 receptors with $\beta 1$ and $\beta 2$ adrenoceptors [22]. $\mathrm{P} 1$ and $\mathrm{P} 2$ receptors are also functionally linked via the actions of cell surface ectonucleotidases which generate adenosine from the metabolism of nucleotides released from cells, permitting sequential activation of $\mathrm{P} 2$ and then $\mathrm{P} 1$ receptors. For example, in sympathetic cotransmission, ATP constricts blood vessels via smooth muscle $\mathrm{P} 2 \mathrm{X} 1$ receptors, and its metabolite adenosine acts as a brake at prejunctional P1 (A1 subtype) receptors to inhibit neurotransmitter release [15]. Extracellular nucleotide levels are controlled through their hydrolysis by families of ectonucleotidases including the ectonucleoside triphosphate diphosphohydrolase (ENTPDase) family which rapidly hydrolyses extracellular tri - and diphosphate nucleotides (including ATP and ADP to AMP; UTP and UDP to UMP) and ecto -5 ' -nucleotidase, the main enzyme responsible for the conversion of AMP to adenosine [23, 24], and also by their cellular reuptake via plasma membrane nucleoside transporters.

\section{$P 1$ and $P 2$ receptor expression in the cardiovascular system}

$\mathrm{P} 1$ and P2 receptors are widely expressed throughout the cardiovascular system, and their effects include modulation of heart function, vascular tone, angiogenesis, and inflammation. P1 adenosine receptors expressed on the vascular smooth muscle, endothelium, and heart are generally vasodilator and cardioprotective $[4,5,15,16]$. $\mathrm{P} 2 \mathrm{X}$ and $\mathrm{P} 2 \mathrm{Y}$ receptors are expressed in the heart and in general have ionotropic effects, amplify sympathetic neurotransmission, and increase myocyte contractility $[15,25-28]$. The vascular smooth muscle expresses $\mathrm{P} 2 \mathrm{X} 1$ receptors which mediate vasocontractile responses to ATP released as a co-transmitter with noradrenaline from sympathetic nerves. Pre-junctional purine receptors include $\mathrm{A} 1$ adenosine and $\mathrm{P} 2 \mathrm{Y}$ receptors on sympathetic nerves and $\mathrm{P} 2 \mathrm{X} 2 / 3$ receptors at the central terminals and axons of sensory nerves [15]. Vasocontractile P2Y2, P2Y4, and $\mathrm{P} 2 \mathrm{Y} 6$ receptors, and in some vessels $\mathrm{P} 2 \mathrm{Y} 14$ receptors, are also expressed in vascular smooth muscle, and vasorelaxant $\mathrm{P} 2 \mathrm{Y} 1, \mathrm{P} 2 \mathrm{Y} 2, \mathrm{P} 2 \mathrm{Y} 4$, and P2Y6 receptors are expressed on the vascular endothelium [15, 16, 29-34]. Endothelial cells also express P2X4 receptors which contribute to vasodilation during shear stress and vascular remodelling [35]. P1 and P2 receptors are also expressed on erythrocytes, platelets, and immune cells $[4,15,25]$.

\section{Roles of purines in the cardiovascular system}

Vascular tone regulation: ATP neurotransmission It is now accepted that ATP is a vasocontractile cotransmitter in sympathetic nerves in most blood vessels and a vasodilator non-adrenergic non-cholinergic (NANC) cotransmitter in some blood vessels. Geoff had discovered that ATP is an inhibitory neurotransmitter in NANC nerves in gut, and he later called these and other nerves found to utilize ATP as a neurotransmitter "purinergic nerves" [36, 37]. This discovery was important because it provided evidence for physiologically relevant signalling by endogenous extracellular nucleotides. Geoff also proposed that a single nerve may utilize multiple neurotransmitters including ATP; cotransmission [38]. The relevance of these concepts for the cardiovascular system is evident in sympathetic cotransmission of ATP with noradrenaline and neuropeptide $\mathrm{Y}$ as shown by Geoff and other researchers in many different blood vessels (see [39, 40]) and for NANC cotransmission of ATP with nitric oxide in rabbit portal vein $[41,42]$.

The receptors involved in sympathetic neurogenic vasoconstriction to ATP were pharmacologically characterized as $\mathrm{P} 2 \mathrm{X}$ receptors [2]. The use of tissue from $\mathrm{P} 2 \mathrm{X} 1$ receptordeficient mice later confirmed an involvement of P2X1 receptors, and by implication ATP, in sympathetic cotransmission [43]. It is now accepted that $\mathrm{P} 2 \mathrm{X} 1$ receptors are widely expressed in vascular smooth muscle and mediate excitatory junction potentials and vasoconstriction induced by ATP released during sympathetic cotransmission. There is an increased density of P2X1 receptors at the neuroeffector junction in arterial smooth muscle and cardiac myocytes; they are clustered in lipid rafts and adjacent to sympathetic nerve varicosities from which neurotransmitter is released by exocytosis [44-46]. At high pressure ATP is the predominant sympathetic neurotransmitter in resistance arteries [47], and elevated tone of blood vessels also increases the purinergic component of sympathetic vasoconstriction [48]. The P2X1 receptor rapidly desensitizes which terminates the purinergic vasocontractile response, and receptor sensitivity can be restored following the removal of ATP by its rapid metabolism by ectonucleotidases. Smooth muscle P2Y receptors may be involved in noradrenaline-mediated vasoconstriction involving ATP release via pannexins complexed with $\alpha 1$ adrenoceptors [49].

Vascular tone regulation: hypoxia, shear stress, and tonic release of purines Endothelial cells form the innermost layer of blood vessels and, in healthy tissues, provide an ongoing vasodilator tone and inhibit platelet aggregation through the release of factors including nitric oxide, prostacyclin, and hyperpolarising factors. Geoff was interested in the dual control of blood vessel contractility involving perivascular nerves in the adventitia (outermost layer) and endothelial cells adjacent to the vascular lumen. He, with colleagues, showed that ATP is released from endothelial cells and acts as an auto/ paracrine signalling molecule at vasodilator endothelial $\mathrm{P} 2 \mathrm{Y}$ receptors; the most common are $\mathrm{P} 2 \mathrm{Y} 1$ receptors sensitive to 
ADP and ATP, P2Y2 receptors sensitive to ATP and UTP, and P2Y6 receptors sensitive to UDP. Measurement of physiologically relevant ATP release from cells is challenging because its extracellular concentration is normally kept low (subnanomlar levels) in tissues by rapid degradation by cell surface ectonucleotidases. Another hurdle was that the high intracellular concentration of ATP $(\mathrm{mM})$, which provides a gradient for its release from cells given the appropriate stimuli, meant that high background levels of ATP were an issue due to inadvertent release of ATP by mechanical stimulation and from damaged cells. It sometimes felt that just looking at the preparations caused ATP to pour out. Geoff and colleagues were tenacious and measured an increase in extracellular ATP levels during hypoxia in the heart, concomitant with coronary hypoxic vasodilatation, and also showed that exogenous ATP is a coronary vasodilator [50-52], thus providing evidence that ATP as well as adenosine $[53,54]$ is a local mediator of hypoxic vasodilatation in the coronary vasculature. Since the in vitro heart preparation was perfused with physiological solution the source of the released ATP was likely the coronary vascular endothelium and there is evidence that hypoxic release of ATP from endothelial cells may be vesicular $[55,56]$. Hypoxia also induces ATP release from erythrocytes [57, 58] which can contribute to vasodilatation during hypoxia and ischaemia in vivo.

ATP release from endothelial cells is also stimulated by shear stress. The concept of ATP as a local vasodilator during shear stress has gained considerable support since Geoff and colleagues measured an increase in extracellular ATP and UTP levels during an increase in perfusion flow rate in vascular beds and cultured endothelial cell preparations [55, 59-62]. Investigations using mice deficient in endothelial $\mathrm{P} 2 \mathrm{Y} 2$ receptors showed that endothelial P2Y2 receptors are involved in flow-induced vasodilatation, eNOS activation, and blood pressure control - the mice developed hypertension [63]. Experiments using P2X4 receptor-deficient mice showed that P2X4 receptors in vascular endothelial cells contribute to vasodilation during shear stress and in vascular remodelling [35]. P2Y1 receptors were shown to be involved in the increase in coronary blood flow following a period of ischaemia in pig hearts implying an auto-/paracrine role for locally released ATP/ADP, possibly from endothelial cells, cardiomyocytes, erythrocytes, and platelets [64].

Shear stress, mechanical deformation, hypoxia, and low $\mathrm{pH}$ release ATP from erythrocytes which causes vasodilatation via endothelial P2Y receptors [57, 58, 65-67].

Myogenic tone involves contractile P2Y6 receptors, tonic release of endogenous pyrimidine nucleotides and possibly connexin hemichannels and P2X7 receptors in mouse mesenteric resistance arteries [68]. Myogenic tone of cerebral arterioles is mediated via direct mechanical activation of vasocontractile $\mathrm{P} 2 \mathrm{Y} 4$ and $\mathrm{P} 2 \mathrm{Y} 6$ receptors rather than the release of endogenous pyrimidine nucleotides [69]. ATP is tonically released from glial cells in rat retinal arterioles in vivo and acts on P2X1 receptors on vascular smooth muscle cells to maintain basal contractile tone [70].

Cardiovascular diseases, cell damage, inflammation and injury, and trophic signalling Damage to cells leads to high extracellular levels of nucleotides which can act at smooth muscle vasocontractile $\mathrm{P} 2 \mathrm{X} 1$ and $\mathrm{P} 2 \mathrm{Y}$ receptors to contribute to vasospasm [15]. ATP can be released from endothelial cells, smooth muscle cells, cardiomyocytes, and erythrocytes by mechanical stimuli including shear and osmotic stress, via mechanisms which include connexin and pannexin channels, which may be relevant in cardiovascular physiology and pathophysiology [71-74]. Nucleotides are released from other cell types including leucocytes and platelets during inflammation and injury $[15,72,75]$.

Geoff was interested in purinergic long-term trophic and inflammatory signalling which occurs in vascular remodelling, restenosis, and atherosclerosis and the evidence for dysfunctional purinergic signalling in cardiovascular diseases including hypertension, diabetes, and thrombosis and in heart conditions $[15,25,27,76]$. Adenosine receptors are involved in angiogenesis through regulating levels of pro- and antiangiogenic factors including VEGF and basic fibroblast growth factor; the process is influenced by the relative expression levels of the four adenosine receptors which can vary depending on the inflammatory conditions [77]. A2A receptors are involved in angiogenesis in the retina and deletion of the receptors reduced neovascularisation in mice [78]. Ectonucleotidases (ENTPDase1 and ecto-5'nucleotidase) have roles in angiogenesis [79]. P2Y2 receptors are involved in endothelial cell sprouting and blood vessel growth $[80,81]$. Tumour hypoxia in cancer activates proangiogenic signalling and generates a chaotic and leaky tumour vasculature which promotes tumour growth and dispersal. Hypoxia in tumours can generate increased extracellular levels of ATP within tumours [82]. Roles for P2X7 and P2Y11 receptors have been described in ATP-mediated inhibition of tumour endothelial cell migration [83].

Deletion of $\mathrm{P} 2 \mathrm{Y} 2$ receptors on endothelial cells promotes atherosclerotic plaque stability [84]. P2X1 receptor activation can inhibit smooth muscle cell proliferation [85]. Individuals with type 2 diabetes have reduced tissue perfusion, lower plasma ATP concentrations and lower blood flow during exercise and hypoxia and impaired endothelium-dependent vasodilatation compared with controls [86]. Release of ATP from cells by mechanical stimulation (including shear stress, osmotic pressure, strain and compression) is elevated in inflammation and injury and is attenuated in hereditary and metabolic conditions including erythrocytes in cystic fibrosis [74].

Perivascular adipose tissue (PVAT), a layer of fatty tissue which surrounds blood vessels, is now known to release a variety of adipokines and other factors which regulate vascular tone $[87,88]$. Adipose tissue expresses P2 receptors which 
can be activated by ATP released from perivascular sympathetic nerves to regulate lipolysis [89-91], and there is evidence for constitutive release of nucleotides from adipocytes in regulation of lipolysis [92]. In obesity, the increase in adipocyte area and mass leads to hypoxia [88]. Since hypoxia stimulates purine release from cells, the role of purinergic signalling in PVAT in vascular tone regulation and remodelling requires further investigation.

Platelets express P2Y1, P2Y12, and P2X1 receptors [93]. The P2Y12 receptor antagonists clopidogrel, prasugrel, and tricagrelor are used in the treatment of thrombosis, stroke, and myocardial infarctions in patients. Purine receptors, ectonucleotidases, and purinergic release and uptake mechanisms are potential therapeutic targets in cardiovascular disease.

\section{Memories of Geoff's laboratory at UCL ( 1985-1997)}

Geoff was a positive force at the Department of Anatomy, UCL where he and his team of dedicated postdocs and PhD students made discoveries on the expression and roles of purine receptors in the cardiovascular and other systems. Geoff understood the need for collaboration and translational research in science- his office was a hub for meetings with clinicians and leaders in the field - and the importance of being abreast of new scientific research techniques, which he achieved by bringing the expertise to his laboratory or through external collaborations. Geoff travelled frequently to conferences throughout the world where he appeared to adopt scientists - each trip seemed to be followed by the addition of a new visiting scientist or $\mathrm{PhD}$ student to the group. This led to a very eclectic, multicultural, and multinational team which contributed to the group's vibrancy and promoted ideas and collaborations. The camaraderie was great. Geoff supported and looked after his team. There were frequent seminars with, importantly, post-seminar food and wine to facilitate discussions. We had fun. Geoff recognized the importance of young scientists and encouraged them. A student's first accepted paper or successful completion of their $\mathrm{PhD}$ was celebrated (more food and wine) and Geoff would seek out the student to give them his warm congratulations.

Individual research meetings were held monthly in Geoff's magnificent high-ceilinged office at UCL. Banks of filing cabinets lined the walls and held thousands of research articles (photocopying journal articles in the library in the days before the internet was a way for $\mathrm{PhD}$ students to earn extra funds); Geoff knew exactly the location of each publication and its content and would pull out articles to illustrate a point. Typically Geoff would chat about news about himself or others before discussing lab results and his openness fostered trust and engagement. He made each one of us feel valued. Geoff jotted down ideas in handwriting that was as exuberant as he was but not always easy to read. He expected full commitment which he generally achieved through his enthusiasm, praise, and encouragement. At one research meeting I mentioned an interest in visiting Australia and Geoff later facilitated this by encouraging me to apply for a Royal Society Travel Fellowship and identified colleagues of his in Melbourne as potential hosts. I thank him also for his support in my application to the Royal Society for a University Research Fellowship, which led to us collaborating with Professor Mike Spyer to investigate purinergic signalling in central nervous system control of the cardiovascular system at the Royal Free Hospital School of Medicine, London [94, 95]. Geoff was a great mentor.
Fig. 1 Geoff Burnstock with Maria Teresa Miras-Portugal at the 6th International Symposium on Adenosine and Adenine Nucleotides, Ferrara, Italy, May 1998

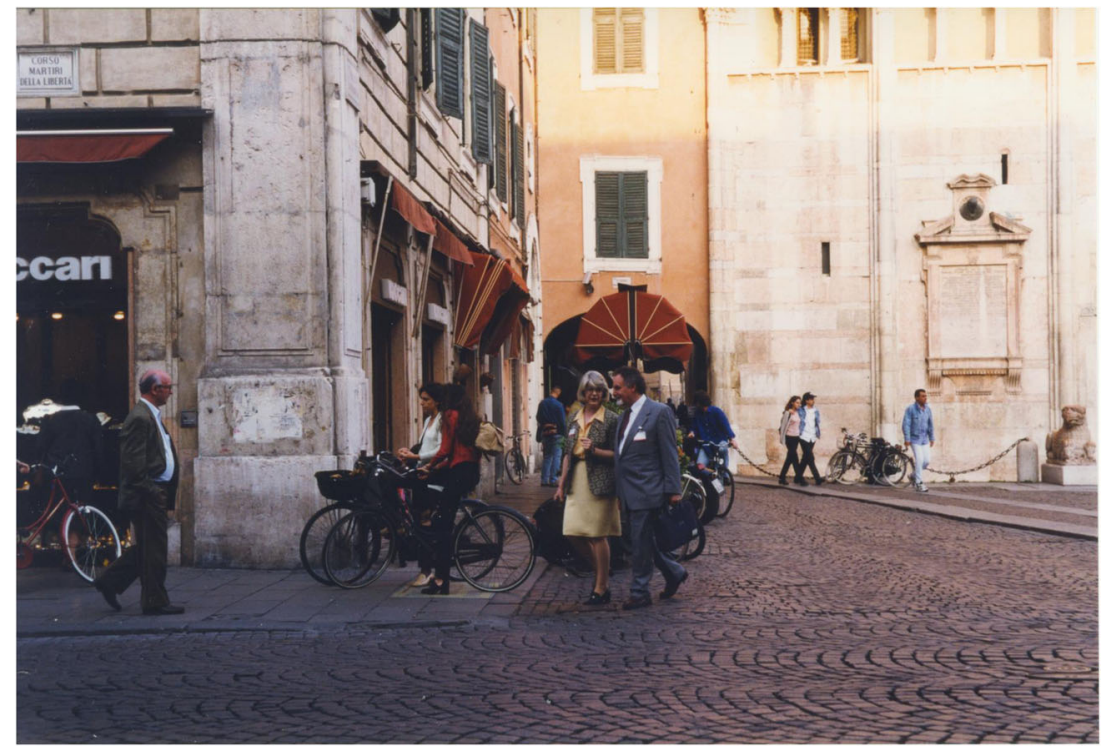




\section{Conclusion}

Geoff championed the role of ATP as an extracellular signalling molecule despite opposition to the concept that ATP was other than an intracellular energy source, and he was fearless and unshakeable in his conviction $[39,40]$. Our understanding of purinergic signalling in the cardiovascular system has been shaped by Geoff Burnstock through his groundbreaking discoveries. Geoff thrived on interactions with the international scientific community, and he promoted communication and collaboration through his initiation of the Purine Clubs and his journal Purinergic Signalling. A photograph of Geoff which I took at the 6th International Symposium on Adenosine and Adenine Nucleotide in Ferrara, Italy (1998) (Figure 1) is one of my favourites and is how I like to remember Geoff-animated, engrossed in conversation (here with Maria Teresa Miras -Portugal) and always chatting about purines. Geoff shone. Geoff lives on through his enormous scientific contribution and in our memories.

\section{Compliance with ethical standards}

Conflicts of interest Vera Ralevic declares that she has no conflict of interest.

Ethical approval This article does not contain any studies with human participants or animals performed by any of the authors.

Open Access This article is licensed under a Creative Commons Attribution 4.0 International License, which permits use, sharing, adaptation, distribution and reproduction in any medium or format, as long as you give appropriate credit to the original author(s) and the source, provide a link to the Creative Commons licence, and indicate if changes were made. The images or other third party material in this article are included in the article's Creative Commons licence, unless indicated otherwise in a credit line to the material. If material is not included in the article's Creative Commons licence and your intended use is not permitted by statutory regulation or exceeds the permitted use, you will need to obtain permission directly from the copyright holder. To view a copy of this licence, visit http://creativecommons.org/licenses/by/4.0/.

\section{References}

1. Burnstock G (1978) A basis for distinguishing two types of purinergic receptor. In: Straub RW, Bolis L (eds) Cell membrane receptors for drugs and hormones: a multidisciplinary approach. Raven Press, New York, pp 107-118

2. Burnstock G, Kennedy C (1985) Is there a basis for distinguishing two types of P2-purinoceptor? Gen Pharmacol 16(5):433-440. https://doi.org/10.1016/0306-3623(85)90001-1

3. Burnstock G (2018) Purine and purinergic receptors. Brain Neurosci Adv 2:239821281881749. https://doi.org/10.1177/ 2398212818817494

4. Fredholm BB, IJzerman AP, Jacobson KA (2001) International union of pharmacology. XXV: nomenclature and classification of adenosine receptors. Pharmacol Rev 53(4):527-552
5. Fredholm BB, Frenguelli BG, Hills R, IJzerman AP, Jacobson KA, Klotz KN, Linden J, Müller CE, Schwabe U, Stiles GL (2019). Adenosine receptors (version 2019.4) in the IUPHAR/BPS Guide to Pharmacology Database. IUPHAR/BPS Guide to Pharmacology CITE 2019(4). Available from: https://doi.org/10.2218/gtopdb/F3/ 2019.4

6. Jacobson KA, Gao Z-G (2006) Adenosine receptors as therapeutic targets. Nat Rev Drug Discov 5(3):247-264

7. Webb TE, Simon J, Krishek BJ, Bateson AN, Smart TG, King BF, Burnstock G, Barnard EA (1993) Cloning and functional expression of a brain G protein-coupled ATP receptor. FEBS Lett 324: 219-225

8. Lustig KD, Shiau AK, Brake AJ (1993) Expression cloning of an ATP receptor from mouse neuroblastoma cells. Proc Natl Acad Sci U S A 90(11):5113-5117

9. Brake AJ, Wagenbach MJ, Julius D (1994) New structural motif for ligand-gated ion channels defined by an ionotropic ATP receptor. Nature 371(6497):519-523

10. Valera S, Hussy N, Evans RJ (1994) A new class of ligand-gated ion channel defined by $\mathrm{P} 2 \mathrm{X}$ receptor for extra-cellular ATP. Nature 371(6497):516-519

11. Abbracchio MP, Burnstock G (1994) Purinoceptors: are there families of P2X and P2Y purinoceptors? Pharmacol Ther 64(3):445475

12. Di Virgilio F, Evans RJ, Falzoni S, Jarvis MF, Kennedy C, Khakh BS, King B, Pellegatti P, Peters JA (2019). P2X receptors (version 2019.4). IUPHAR/BPS guide to pharmacology CITE 2019(4)

13. North RA (2002) Molecular physiology of P2X receptors. Physiol Rev 82(4):1013-1067. https://doi.org/10.1152/physrev.00015. 2002

14. Burnstock G (2007) Purine and pyrimidine receptors. Cell Mol Life Sci 64:14711483

15. Burnstock G, Ralevic V (2014) Purinergic signalling and blood vessels in health and disease. Pharmacol Rev 66(1):102-192

16. Ralevic V, Burnstock G (1998) Receptors for purines and pyrimidines. Pharmacol Rev 50(3):413-492

17. Abbracchio MP, Burnstock G, Boeynaems J-M (2006) International union of pharmacology: update on the P2Y G protein-coupled nucleotide receptors: from molecular mechanisms and pathophysiology to therapy. Pharmacol Rev 58(3):281-341

18. Erb L, Weisman GA (2012) Coupling of P2Y receptors to G proteins and other signalling pathways. Wiley Interdiscip Rev Membr Transp Signal 1:789-803

19. Suzuki T, Namba K, Tsuga H, Nakata H (2006) Regulation of pharmacology by hetero-oligomerization between A1 adenosine receptor and $\mathrm{P} 2 \mathrm{Y} 2$ receptor. Biochem Biophys Res Commun 351:559-565

20. Yoshioka K, Saitoh O, Nakata H (2001) Heteromeric association creates a P2Y-like adenosine receptor. Proc Natl Acad Sci U S A 98:7617-7622

21. Shrestha SS, Parmar M, Kennedy C, Bushell TJ (2010) Two-pore potassium ion channels are inhibited by both $\mathrm{G}(\mathrm{q} / 11)$ - and $\mathrm{G}(\mathrm{i})$ coupled P2Y receptors. Mol Cell Neurosci 43:363-369

22. Chandrasekera PC, Wan TC, Gizewski ET, Auchampach JA, Lasley RD (2013) Adenosine A1 receptors heterodimerize with b1- and b2-adrenergic receptors creating novel receptor complexes with altered $G$ protein coupling and signalling. Cell Signal 25(4): 736-742

23. Yegutkin GG (2008) Nucleotide- and nucleoside-converting ectoenzymes: Important modulators of purinergic signalling cascade. Biochim Biophys Acta 1783:673-694

24. Zimmermann H, Zebisch M, Strater N (2012) Cellular function and molecular structure of ecto-nucleotidases. Purinergic Signal 8:437502 
25. Burnstock $G$ (2017) Purinergic signalling in the cardiovascular system. Circ Res 120:207-228. https://doi.org/10.1161/ CIRCRESAHA.116.309726

26. Burnstock G, Pelleg A (2015) Cardiac purinergic signalling in health and disease. Purinergic Signal 11(1):1-46. https://doi.org/ 10.1007/s11302-014-9436-1

27. Erlinge D, Burnstock G (2008) P2 receptors in cardiovascular regulation and disease. Purinergic Signal 4(1):1-20

28. Ralevic V (2012) P2X receptors in the cardiovascular system. Wiley Interdiscip Rev Membr Transp Signal 2012(1):663-674. https://doi.org/10.1002/wmts.58

29. Abbas ZSB, Latif ML, Dovlatova N, Fox SC, Heptinstall S, Dunn WR, Ralevic V (2018) UDP-sugars activate $\mathrm{P}^{2} \mathrm{Y}_{14}$ receptors to mediate vasoconstriction of the porcine coronary artery. Vasc Pharmacol 103-105:36-46

30. Alsaqati M, Latif ML, Chan SLF, Ralevic V (2014) Novel vasocontractile role of the $\mathrm{P}_{2} \mathrm{Y}_{14}$ receptor: characterization of its signalling in porcine isolated pancreatic arteries. $\mathrm{Br} \mathrm{J}$ Pharmacol 171(3):701-713

31. Haanes KA, Edvinsson L (2014) Characterization of the contractile $\mathrm{P} 2 \mathrm{Y}_{14}$ receptor in mouse coronary and cerebral arteries. FEBS Lett 588:2936-2943

32. Malmsjo M, Adner M, Harden TK, Pendergast W, Edvinsson L, Erlinge D (2000) The stable pyrimidines UDP $\beta S$ and UTP $\gamma$ S discriminate between the $\mathrm{P} 2$ receptors that mediate vascular contraction and relaxation of the rat mesenteric artery. Br J Pharmacol 131: 5156

33. Ralevic V, Dunn WR (2015) Purinergic transmission in blood vessels. Purinergic Signal 191:48-66

34. Rayment SJ, Latif ML, Ralevic V, Alexander SPH (2007) Evidence for the expression of multiple uracil nucleotide-stimulated P2 receptors coupled to smooth muscle contraction in porcine isolated arteries. Br J Pharmacol 150(5):604-612

35. Yamamoto K, Sokabe T, Matsumoto T, Yoshimura K, Shibata M, Ohura N, Fukuda T, Sato T, Sekine K, Kato S, Isshiki M, Fujita T, Kobayashi M, Kawamura K, Masuda H, Kamiya A, Ando J (2006) Impaired flow-dependent control of vascular tone and remodelling in P2X4-deficient mice. Nat Med 12:133-137

36. Burnstock G (1972) Purinergic nerves. Pharmacol Rev 24(3):509_ 581

37. Burnstock G, Campbell G, Satchell D, Smythe A (1970) Evidence that adenosine triphosphate or a related nucleotide is the transmitter substance released by non-adrenergic inhibitory nerves in the gut. Br J Pharmacol 40:668-688

38. Burnstock G (1976) Do some nerve cells release more than one transmitter? Neuroscience 1:239-248

39. Burnstock G (2006) Purinergic signalling. Br J Pharmacol 147: S172-S187. https://doi.org/10.1038/sj.bjp.0706429

40. Burnstock G (2012) Discovery of purinergic signalling, the initial resistance and current explosion of interest. Br J Pharmacol 167(2): 238-255. https://doi.org/10.1111/j.1476-5381.2012.02008.x

41. Brizzolara AL, Crowe R, Burnstock G (1993) Evidence for the involvement of both ATP and nitric oxide in non-adrenergic, noncholinergic inhibitory neurotransmission in the rabbit portal vein. Br J Pharmacol 109(3):606-608

42. Kennedy C, Burnstock G (1985) Evidence for two types of P2purinoceptor in longitudinal muscle of the rabbit portal vein. Eur J Pharmacol 111(1):49-56

43. Vial C, Evans RJ (2002) P2X1 receptor-deficient mice establish the native $\mathrm{P} 2 \mathrm{X}$ receptor and a $\mathrm{P} 2 \mathrm{Y} 6$-like receptor in arteries. $\mathrm{Mol}$ Pharmacol 62(6):1438-1445

44. Hansen MA, Bennett MR, Barden JA (1999a) Distribution of purinergic P2X receptors in the rat heart. J Auton Nerv Syst 78: $1-9$
45. Hansen MA, Dutton JL, Balcar VJ, Barden JA, Bennett MR (1999b) P2X (purinergic) receptor distributions in rat blood vessels. J Auton Nerv Syst 75:147-155

46. Vial C, Evans RJ (2005) Disruption of lipid rafts inhibits P2X1 receptor-mediated currents and arterial vasoconstriction. J Biol Chem 280:30705-30711

47. Rummery NM, Brock JA, Pakdeechote P, Ralevic V, Dunn WR (2007) ATP is the predominant sympathetic neuro-transmitter in rat mesenteric arteries at high pressure. J Physiol 582(2):745-754

48. Pakdeechote P, Rummery NM, Ralevic V, Dunn WR (2007) Raised tone reveals purinergic-mediated responses to sympathetic nerve stimulation in the rat per-fused mesenteric vascular bed. Eur J Pharmacol 563:180-186

49. Billaud M, Lohman AW, Straub AC, Looft-Wilson R, Johnstone SR, Araj CA, Best AK, Chekeni FB, Ravichandran KS, Penuela S, Laird DW, Isakson BE (2011) Pannexin1 regulates alpha1adrenergic receptor- mediated vasoconstriction. Circ Res 109:8085

50. Hopwood AM, Burnstock G (1987) ATP mediates coronary vasoconstriction via $\mathrm{P} 2 \mathrm{x}$-purinoceptors and coronary vasodilatation via $\mathrm{P} 2 \mathrm{y}$-purinoceptors in the isolated perfused rat heart. Eur J Pharmacol 136:49-54

51. Hopwood AM, Lincoln J, Burnstock G (1989) Adenosine 5'-triphosphate, adenosine and endothelium-derived relaxing factor in hypoxic vasodilatation of the heart. Eur J Pharmacol 165(2-3): 323-326

52. Vials AJ, Burnstock G (1996) ATP release from the isolated perfused guinea pig heart in response to increased flow 33(1):1-4

53. Berne RM (1963) Cardiac nucleotides in hypoxia: possible role in regulation of coronary blood flow. Am J Phys 204:317-322

54. Berne RM (1980) The role of adenosine in the regulation of coronary blood flow. Circ Res 47:807-813

55. Bodin P, Burnstock G (2001) Evidence that release of adenosine triphosphate from endothelial cells during increased shear stress is vesicular. J Cardiovasc Pharmacol 38(6):900-908

56. Lim To WK, Kumar P, Marshall JM (2015) Hypoxia is an effective stimulus for vesicular release of ATP from human umbilical vein endothelial cells. Placenta 36(7):759-766

57. Bergfeld GR, Forrester T (1992) Release of ATP from human erythrocytes in response to a brief period of hypoxia and hypercapnia. Cardiovasc Res 26:40-47

58. Ellsworth ML, Ellis CG, Sprague RS (2016) Role of erythrocytereleased ATP in the regulation of microvascular oxygen supply in skeletal muscle. Acta Physiol 216:265-276. https://doi.org/10. 1111/apha.12596

59. Bodin P, Bailey D, Burnstock G (1991) Increased flow-induced ATP release from isolated vascular endothelial cells but not smooth muscle cells. Br J Pharmacol 103(1):1203-1205

60. Milner P, Kirkpatrick KA, Ralevic V, Toothill V, Pearson J, Burnstock G (1990) Endothelial cells cultured from human umbilical vein release ATP, substance $P$ and acetylcholine in response to increased flow. Proc R Soc Lond Ser B Biol Sci 241(1302):245248

61. Ralevic V, Milner P, Kirkpatrick KA, Burnstock G (1992) Flowinduced release of adenosine 5'-triphosphate from endothelial cells of the rat mesenteric arterial bed. Experientia 48(1):31-34

62. Saiag B, Bodin P, Shacoori V, Catheline M, Rault B, Burinstock G (1995) Uptake and flow-induced release of uridine nucleotides from isolated vascular endothelial cells. Endothelium 2(4):279-285

63. Wang SP, Iring A, Strilic B, Juarez JA, Kaur H et al (2015) P2Y2 and $\mathrm{Gq} / \mathrm{G} 11$ control blood pressure by mediating endothelial mechanotransduction. J Clin Invest 125(8):3077-3086

64. Olivecrona G, Gotberg M, Harnek J, Wang L, Jacobson KA, Erlinge D (2004) Coronary artery reperfusion: the ADP receptor P2Y1 mediates early reactive hyperemia in pigs. Purinergic Signal 1(1):59-65 
65. Dietrich HH, Ellsworth ML, Sprague RS, Dacey RG Jr (2000) Red blood cell regulation of microvascular tone through adenosine triphosphate. Am J Physiol Heart Circ Physiol 278:H1294-H1298. https://doi.org/10.1152/ajpheart.2000.278.4.H1294

66. Ellsworth ML, Forrester T, Ellis CG, Dietrich HH (1995) The erythrocyte as a regulator of vascular tone. Am J Phys 269: $\mathrm{H} 2155-\mathrm{H} 2161$

67. Wang L, Olivecrona G, Götberg M, Olsson ML, Winzell MS, Erlinge D (2005) ADP acting on P2Y13 receptors is a negative feedback pathway for ATP release from human red blood cells. Circ Res 96:189-196. https://doi.org/10.1161/01.RES. 0000153670.07559.E4

68. Kauffenstein G, Tamareille S, Prunier F, Roy C, Ayer A, Toutain B (2016) Central role of P2Y6 UDP receptor in arteriolar myogenic tone. Arterioscler Thromb Vasc Biol 36(8):1598-1606

69. Brayden JE, Li Y, Tavares MJ (2013) Purinergic receptors regulate myogenic tone in cerebral parenchymal arterioles. J Cereb Blood Flow Metab 33(2):293-299

70. Kur J, Newman EA (2014) Purinergic control of vascular tone in the retina. J Physiol 592(3):491-504

71. Dahl G (2015) ATP release through pannexon channels. Philos Trans R Soc Lond Ser B Biol Sci 370(1672):20140191

72. Lazarowski ER (2012) Vesicular and conductive mechanisms of nucleotide release. Purinergic Signal 8(3):359-373. https://doi. org/10.1007/s11302-012-9304-9

73. Lohman AW, Billaud M, Isakson BE (2012) Mechanisms of ATP release and signalling in the blood vessel wall. Cardiovasc Res 95(3):269-280

74. Mikolajewicz N, Mohammed A, Morris M, Komarova SV (2018) Mechanically stimulated ATP release from mammalian cells: systematic review and meta-analysis. J Cell Sci 131:jcs223354. https:// doi.org/10.1242/jcs.223354

75. Lazarowski ER, Harden TK (1999) Quantitation of extracellular UTP using a sensitive enzymatic assay. Br J Pharmacol 127(5): $1272-1278$

76. Burnstock G (2016) Short- and long term (trophic) purinergic signalling. Philos Trans R Soc Lond B Biol Sci 371:20150422. https:// doi.org/10.1098/rstb.2015.0422

77. Feoktistov I, Biaggioni I, Cronstein BN (2009) Adenosine receptors in wound healing, fibrosis and angiogenesis. Handb Exp Pharmacol 193:383-397

78. Liu Z, Yan S, Wang J, Xy Y, Wang Y et al (2017) Endothelial adenosine A2a receptor-mediated glycolysis is essential for pathological retinal angiogenesis. Nat Commun 8:584. https://doi.org/10. 1038/s41467-017-00551-2

79. Leone RD, Emens LA (2018) Targeting adenosine for cancer immunotherapy. J Immunother Cancer 6:57

80. Muhleder S, Fuhs C, Basilio J, Szwarc D, Pill K et al (2019) Purinergic P2Y2 receptors modulate endothelial sprouting. Cell Mol Life Sci 77(5):885-901

81. Mühleder S, Fuchs C, Basílio J, Szwarc D, Pill K, Labuda K, Slezak P, Siehs C, Pröll J, Priglinger E, Hoffmann C, Junger WG, Redl H,
Holnthoner W (2020) Purinergic P2Y2 receptors modulate endothelial sprouting. Cell Mol Life Sci 77(5):885-901

82. Di Virgilio F, Sarti AC, Falzoni S, De Marchi E, Adinolf E (2018) Extracellular ATP and p2 purinergic signalling in the tumour microenvironment. Nat Rev Cancer 18:601-618

83. Avanzato D, Genova T, Fiorio Pla A, Bernardini M, Bianco S, Bussolati B, Mancardi D, Giraudo E, Maione F, Cassoni P, Castellano I, Munaron L (2016) Activation of P2X7 and P2Y11 purinergic receptors inhibits migration and normalizes tumorderived endothelial cells via cAMP signaling. Sci Rep 6:32602

84. Chen X, Qian S, Hoggatt A, Tang H, Hacker TA, Obukhov AG, Herring PB, Seye CI (2017) Endothelial cell-specific deletion of $\mathrm{P} 2 \mathrm{Y} 2$ receptor promotes plaque stability in atherosclerosissusceptible ApoE-null mice. Atheroscler Throm Vasc Biol 37(1): 75-83

85. Hinze AV, Mayer P, Harst A, von Kugelgen (2013) P2X1 receptormediated inhibition of the proliferation of human coronary smooth muscle cells involving the transcription factor NR4A1. Purinergic Signal 9(4):677-686

86. Groen MB, Knudsen TA, Finsen SH, Pedersen BK, Hellsten Y, Mortensen SP (2019) Reduced skeletal-muscle perfusion and impaired ATP release during hypoxia and exercise in individuals with type 2 diabetes. Diabetologia 62:485-493

87. Gollasch M (2017) Adipose-vascular coupling and potential therapeutics. Annu Rev Pharmacol Toxicol 57:417-436. https://doi.org/ 10.1146/annurev-pharmtox-010716-104542

88. Xia N, Li H (2017) The role of perivascular adipose tissue in obesity-induced vascular dysfunction. Br J Pharmacol 85:34253442. https://doi.org/10.1111/bph.13650

89. Bulloch JM, Daly CJ (2014) Autonomic nerves and perivascular fat: interactive mechanisms. J Pharmacol Ther 143(1):61-73

90. Burntsock G, Gentile D (2018) The involvement of purinergic signalling in obesity. Purinergic Signal 14(2):97-108

91. Tozzi N, Novak I (2017) Purinergic receptors in adipose tissue as potential targets in metabolic disorders. Front Pharmacol 8:878

92. Ali SB, Turner JJ, Fountain SJ (2018) Constitutive P2Y2 receptor activity regulates basal lipolysis in human adipocytes. J Cell Sci 131(22):jes221994

93. Hechler B, Gachet C (2015) Purinergic receptors in thrombosis and inflammation. Arterioscler Thromb Vasc Biol 35:2307-2315

94. Ralevic V, Thomas T, Burnstock G, Spyer KM (1999) Characterization of $\mathrm{P} 2$ receptors modulating neural activity in rat rostral ventrolateral medulla. Neuroscience 94:867-878

95. Thomas T, Ralevic V, Gadd CA, Spyer KM (1999) Central chemoreception; a mechanism involving $\mathrm{P} 2$-purinoceptors localised in the ventrolateral medulla of the anaesthetised rat. J Physiol 517:899 905

Publisher's note Springer Nature remains neutral with regard to jurisdictional claims in published maps and institutional affiliations. 